\title{
STRATEGI PENGEMBANGAN KELEMBAGAAN KELOMPOK NELAYAN SEBAGAI KELEMBAGAAN PENGELOLA WADUK DI PERAIRAN WADUK WADAS LINTANG, KABUPATEN WONOSOBO
}

\author{
Oleh \\ Fatriyandi Nur Priyatna' dan Kunto Purnomo ${ }^{2}$
}

\begin{abstract}
ABSTRAK
Tulisan ini bertujuan untuk mempelajari kelembagaan lokal yang ada di Waduk Wadas Lintang dan peluang serta upaya pengembangannya menjadi kelembagaan pengelola waduk. Penelitian dilakukan di empat desa di Kecamatan Wadas Lintang, Waduk Wadas Lintang, Kabupaten Wonosobo, Propinsi Jawa Tengah pada bulan Agustus - Oktober tahun 2006. Pemilihan ini didasari pertimbangan mengenai konsentrasi nelayan, sifat kelembagaan nelayan yang sudah ada dan aksesibilitas lokasi. Metodologi yang digunakan dalam penelitian ini bersifat kualitatif dan studi kasus intrinsik, yaitu penetapan tujuan penelitian dilakukan berdasarkan ketertarikan suatu fenomena kelembagaan nelayan di perairan waduk. Data primer yang dikumpulkan terkait dengan kelembagaan lokal dan persepsi masyarakat terhadap status pemanfaatan sumberdaya perikanan. Pemilihan informan dilakukan secara sengaja dan pengumpulan data menggunakan teknik wawancara mendalam, diskusi kelompok dan pengamatan. Analisis data menggunakan pendekatan model interaksi dengan alat analisis data berupa pendekatan kelembagaan dan prinsip-prinsip co-management. Hasil penelitian menunjukkan kelembagaan yang ada adalah kelembagaan formal dan kelembagaan informal dan memiliki pengaruh signifikan terhadap faktor penerimaan anggota terhadap keberadaan dan fungsi kelembagaan lokal serta tingkat partisipasi anggota yang lebih tinggi pada kelembagaan formal. Pilihan strategi fasilitasi dapat diterapkan oleh pemerintah dalam upaya pengembangan kelembagaan kelompok nelayan dengan melalui tahapan pembentukan dan penyusunan kelembagaan; penguatan; dan pengembangan kelompok nelayan menggunakan pendekatan partisipasi dan "learning process" dalam semua proses pengambilan keputusan.
\end{abstract}

\section{Kata Kunci : Waduk Wadas Lintang, Kelembagaan Lokal, Kelompok Nelayan, Strategi Fasilitasi}

\section{Abstract : Strategy for Local Fisheries Local Institution Development as Reservoir Management Authority at the Wadas Lintang Reservoir of Wonosobo District. By Fatriyandi Nur Priyatna and Kunto Purnomo}

The objectives of this research were to study local institution at the Wadas Lintang reservoir and its opportunity to be promoted as a reservoir management authority. The research was conducted in August to October 2006 using qualitative and intrinsic case study at four villages of Wadas Lintang Sub District, Wonosobo District, Central Java Province considering fishers concentration sites, current local fishers institution and also sites' accessibility. Primary data were mostly related to current local fishers institution and resource utilization perception which were collected using in depth interview, group discussion and observation from informants which were selected using purposive technique. Data were analyzed descriptively using interaction model technique with institutional theory and co-management principles. Results indicated that there were formal and informal local institution which is significantly influenced to the members' acceptance of institution existence and roles and also the level of member's participation which is higher at formal institution. Facilitating strategy could be chosen by local government as fishers local institution development strategy following the stage of initiating, developing and empowering local institution with participation and learning process approach on each stages.

\section{Key words : Wadas Lintang Reservoir, Local Institution, Fishers Institution, Facilitating Strategy}

\footnotetext{
${ }^{1}$ Peneliti Pada Balai Besar Riset Sosial Ekonomi Kelautan dan Perikanan, BRKP-DKP. JI. KS TUBUN Petamburan VI Slipi Jakarta 10260. Telp. (021) 53650162

${ }^{2}$ Peneliti Pada Loka Riset Pemacuan Stock Ikan, Pusat Riset Perikanan Tangkap, BRKP-DKP
} 


\section{PENDAHULUAN}

Rezim pemerintahan yang memiliki semangat desentralisasi diamanatkan dalam UU No 22 Tahun 1999 tentang Otonomi Daerah yang dalam perjalanannya mengalami penyempurnaan-penyempurnaan hingga akhirnya dikeluarkan UU No 32 Tahun 2004 tentang Pemerintahan Daerah. Desentralisasi dapat diartikan sebagai pendelegasian kewenangan dan tanggungjawab atas fungsifungsi publik dari pemerintah pusat kepada daerah atau lembaga pemerintah semiindependen atau juga kepada swasta dan lembaga masyarakat (Cohen and Peterson, 1999; Rondinelli, 1999; Smith, 1985 dalam Satria and Matsida, 2004). Dengan dikeluarkannya payung hukum atas desentralisasi, maka dimungkinkan pemerintah daerah beserta masyarakat untuk mengoptimalkan sumberdaya yang ada sebagai sebuah bagian dari strategi pembangunan berkelanjutan.

Salah satu wacana yang berkembang terkait dengan pengelolaan dan pemanfaatan sumberdaya perikanan yang selaras dengan pembangunan berkelanjutan adalah konsep co-management. Secara sederhana, comanagement merupakan sebuah konsep pengelolaan sumberdaya yang dilakukan secara bersama-sama antara pemerintah dengan masyarakat (Pomeroy and Berkes, 1997; Jentoft et al, 1998). Konsep pengelolaan secara bersama-sama antara pemerintah dan masyarakat dalam arti yang berbeda juga mensyaratkan adanya pembagian atau pendelegasian kewenangan dari otoritas tertinggi kepada masyarakat (Jentoft et al, 1998). Dalam hal ini salah satu tujuan dari comanagement termasuk di dalamnya adalah menciptakan keikutsertaan yang jauh lebih besar bagi masyarakat dalam proses pengelolaan sumberdaya perikanan, kemandirian kelembagaan lokal dan juga peran serta aktif dalam proses pengambilan keputusan terkait kebijakan pembangunan perikanan (Pomeroy and Berkes, 1997).
Dengan demikian, sebenarnya terdapat hubungan yang erat antara konsep desentralisasi dengan konsep pengelolaan sumberdaya berbasis co-management. Jika dilihat dari tujuan yang ingin dicapai dalam implementasi co-management pada pengelolaan sumberdaya perikanan maka searah dengan semangat dari desentralisasi yaitu menciptakan demokrasi dan pemberdayaan masyarakat. Sementara itu, laporan USAID pada tahun 1983 (Uphoff, 1986), menyebutkan bahwa kelembagaan publik yang efektif merupakan hal yang sangat esensial bagi suatu negara dan mampu memberikan solusi mandiri bagi banyak masalah yang muncul dalam suatu pembangunan. Lebih Ianjut Uphoff menyebutkan bahwa pembangunan dan pengembangan kelembagaan dapat dipandang sebagai suatu jenis investasi jangka panjang dan harus memberikan porsi yang seimbang bagi pengembangan kelembagaan lokal. Penelitian yang dilakukan dalam tulisan ini bertujuan untuk mempelajari kelembagaan lokal yang ada di Waduk Wadas Lintang dan peluang serta upaya pengembangannya menjadi kelembagaan pengelola waduk.

\section{METODE}

\section{Metode Penelitian}

Metodologi yang digunakan dalam penelitian ini bersifat kualitatif, yaitu melibatkan interpretasi dan juga pendekatan naturalistik terhadap subjek penelitian, serta tidak jarang menggunakan berbagai metode atau pendekatan pada satu fokus kajian (Denzin and Lincoln, 1994). Sementara itu, studi kasus digunakan untuk membatasi fokus dan subjek penelitian pada hal-hal atau kasus yang terkait dengan kelembagaan nelayan. Seperti yang dijelaskan oleh Stake (1994) bahwa studi kasus bukanlah sebuah pilihan metodologi penelitian, namun hanya sebuah pilihan untuk meneliti objek atau subjek penelitian. Studi kasus yang digunakan 
bersifat studi kasus intrinsik, yaitu didorong oleh suatu ketertarikan pada suatu fenomena tertentu dan bukan sebagai upaya untuk membangun suatu teori, walaupun tidak dibatasi untuk sama sekali tidak diperkenankan membangun suatu teori (Stake, 1994). Hal yang mendasari penggunaan studi kasus intrinsik adalah adanya keinginan untuk mempelajari dan mengeksplorasi fenomena kelembagaan nelayan yang ada di lokasi penelitian berikut peluang pengembangannya.

\section{Lokasi dan Waktu Penelitian}

Penelitian dilakukan pada empat desa di Kecamatan Wadas Lintang, Waduk Wadas Lintang, Kabupaten Wonosobo, Propinsi Jawa Tengah pada Bulan Agustus Oktober Tahun 2006. Keempat desa tersebut adalah Desa Wadas Lintang, Sumberrejo, Elorejo dan Kaligowong. Keempat desa dipilih berdasarkan hasil analisis data sekunder yaitu hasil penelitian yang telah dilakukan sebelumnya dan diskusi dengan Dinas Peternakan dan Perikanan Kabupaten Wonosobo. Selain itu, pertimbangan pemilihan empat desa juga melihat dari konsentrasi nelayan yang lebih banyak tersebar di keempat desa tersebut, sifat kelembagaan nelayan baik formal dalam bentuk unit koperasi dan non-formal dalam bentuk kelompok nelayan yang sudah ada serta aksesibilitas lokasi.

\section{Sumber Data}

Data primer didapatkan dari para informan yang terdiri dari petugas Dinas Peternakan dan Perikanan Kabupaten Wonosobo dan masyarakat nelayan. Data primer yang dikumpulkan terkait dengan kelembagaan lokal yang ada di masyarakat, seperti sejarah, inisiasi dan tujuan pembentukan, fungsi dan peran kelembagaan. Data terkait persepsi masyarakat terhadap status pemanfaatan sumberdaya perikanan juga dikumpulkan untuk melihat sejauhmana persepsi masyarakat terhadap pentingnya pengelolaan sumberdaya perairan. Sementara data sekunder yang digunakan dalam penelitian ini adalah laporan-laporan statistik perikanan dari Dinas Peternakan dan Perikanan Kabupaten Wonosobo serta hasil-hasil penelitian yang dilakukan oleh PRPT terkait dengan pemanfaatan perairan.

\section{Metode Pemilihan Informan dan Pengumpulan Data}

Pemilihan informan dilakukan secara disengaja bagi informan-informan kunci yaitu ketua kelompok nelayan dan atau pengurus, anggota kelompok nelayan dan petugas penyuluhan. Sementara pengumpulan data primer dilakukan melalui dua teknik, yaitu teknik wawancara mendalam dan pengamatan. Wawancara mendalam dilakukan dengan menggunakan cara dan suasana yang berbeda bagi setiap informan disesuaikan dengan kondisi dan keterbatasan yang ada. Kondisi dan keterbatasan tersebut meliputi ketersediaan waktu, tempat dan alat bantu pengumpulan data. Informan adalah orang-orang yang dianggap banyak mengetahui dan terlibat langsung dalam permasalahan atau kasus yang ada di lokasi penelitian. Pengumpulan data di Desa Wadas Lintang dan Kali Gowong juga dilakukan dengan teknik diskusi oleh kelompok.

\section{Kerangka Pendekatan Studi dan Metode Analisis Data}

Kelembagaan lokal dan keterkaitannya dengan pola pengelolaan dan pemanfaatan sumberdaya perikanan merupakan elemen kunci di dalam upaya-upaya memberdayakan masyarakat untuk mengelola secara bertanggungjawab sumberdaya yang ada sesuai dengan semangat desentralisasi. Terkait dengan tujuan penelitian yang mempelajari kelembagaan lokal di masyarakat nelayan perairan waduk dan upaya-upaya pengembangannya, maka hal-hal seperti faktor dan tujuan pembentukan kelembagaan lokal, representasi keanggotaan, tingkat 
penerimaan anggota, tingkat partisipasi anggota dalam pengambilan keputusan, fungsi kelembagaan lokal sebagai parameter yang diamati. Sementara itu, Uphoff (1986), menyebutkan bahwa terdapat tiga strategi yang berbeda yang mampu dijalankan oleh pemerintah terkait dengan peranan yang dijalankannya. Ketiga pilihan strategi ini mewakili tingkatan yang berbeda dari keterlibatan "pihak luar" dalam permasalahan kelembagaan lokal (kelompok), serta juga mendapatkan gambaran status dan peranan kelembagaan lokal dalam kehidupan pemanfaatan sumberdaya perikanan. Kemudian terkait pilihan strategi pengembangan kelembagaan oleh pemerintah akan dianalisis menggunakan pendekatan yang dikembangkan oleh Uphoff (1986), yaitu pilihan strategi promosi, fasilitasi dan asistensi. Analisis pengembangan kelembagaan didasarkan pada kondisi dan status kelembagaan lokal yang ada dan pilihan

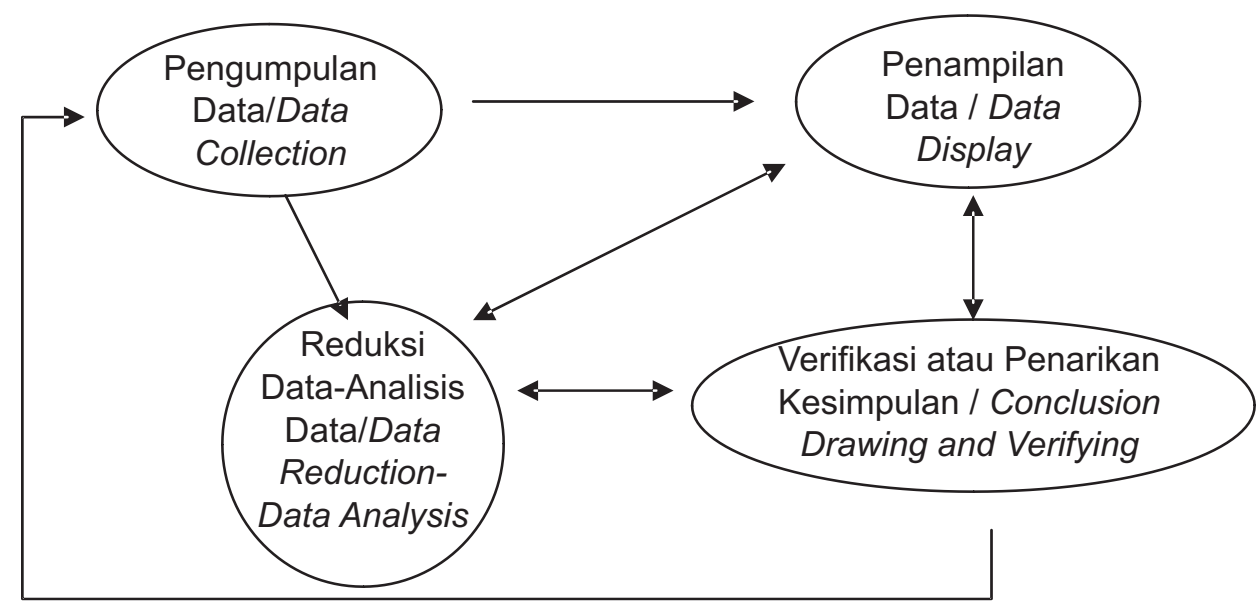

Gambar 1. Skema Analisis Data : Model InteraksiMiles and Huberman, 1994)

Figure 1. Schematic Analytical Data : An Interaction Model (Miles and Huberman, 1994)

mewakili dari tingkat dan pola hubungan yang dikembangkan. Namun demikian, Uphoff (1986) memberikan penekanan bahwa pilihan strategi yang akan digunakan sangat bergantung kepada potensi kelembagaan apa yang telah ada dan asal insiasi perubahan yang mungkin terjadi. Pendekatan "learning process" merupakan pendekatan yang efektif dalam upaya pengembangan kelembagaan lokal di masyarakat.

Analisis data menggunakan pendekatan model interaksi, yaitu melibatkan tiga sub proses kegiatan yang saling terkait yaitu reduksi data, penampilan data dan verifikasi atau penarikan kesimpulan (Gambar 1). Analisis data dimulai dengan mengidentifikasi kelembagaan lokal yang ada di lokasi penelitian yang bertujuan strategi yang diperoleh.

\section{HASIL DAN PEMBAHASAN}

\section{Kelembagaan Lokal Nelayan di Perairan Waduk Wadas Lintang}

Kelembagaan yang ada di Waduk Wadas Lintang, secara umum dapat dikelompokkan menjadi dua, yaitu kelembagaan formal dan kelembagaan informal. Pengelompokkan ini didasarkan pada perbedaan status perkembangan kelompok yang telah berbadan hukum dan tidak. Perbedaan status ini memiliki pengaruh yang signifikan terhadap berjalannya kelembagaan tersebut. Pada kelembagaan kelompok nelayan yang formal, anggota merasa sangat memiliki kelembagaan 
tersebut dan menjadikan kelembagaan kelompok nelayan tersebut sebagai wadah menyalurkan aspirasi. Tingkat partisipasi anggota kelembagaan kelompok nelayan formal terhadap kegiatan kelembagaan secara keseluruhan lebih tinggi dibandingkan dengan kelembagaan informal. Tingkat partisipasi ini dilihat pada antusiasme anggota kelompok untuk menghadiri dan berperan serta dalam segala aktifitas yang ada di kelembagaan tersebut.

Sementara itu, pada kelembagaan kelompok nelayan bersifat informal keberadaan kelompok tidak dirasakan sangat penting. Hal ini diindikasikan dari hasil wawancara yaitu sebagian besar anggota merasa keberadaan kelompok hanya ditujukan untuk mendapatkan bantuan kredit, jika tidak ada maka tidak perlu atau sulit berpartisipasi dalam kelompok. Sebagian besar dari anggota tersebut belum menyadari tujuan dan manfaat dari keberadaan kelompok. Pada akhirnya, dirasakan sangat sulit untuk mengkoordinasikan seluruh nelayan yang ada pada desa tersebut dalam hal pengembangan pengelolaan waduk secara bersama. Hal ini muncul karena masing-masing nelayan pada desa tersebut berpikir bahwa kegiatan usaha dan teknik penangkapan yang mereka lakukan adalah urusan mereka sendiri dan tidak berdampak bagi pihak lain. Implikasinya adalah ketika dihadapkan pada suatu permasalahan, mereka mengambil sikap "pasrah" dan atau bergerak sendiri-sendiri serta tidak terkoordinasi. Namun demikian, pada umumnya mereka tetap memberikan perhatian yang cukup bagi setiap petugas dinas pemerintah yang mendatangi dan memberikan penyuluhan. Status kelembagaan lokal yang ada di Wadas Lintang dapat dilihat pada Tabel 1 .

Pada kelembagaan kelompok nelayan formal dalam perkembangannya telah berhasil berperan sebagai kelembagaan jaminan sosial yang memberikan perlindungan bagi kelangsungan usaha anggotanya. Berdasarkan aturan yang dibuat secara bersama-sama, umumnya setiap kelembagaan kelompok nelayan memiliki iuran yang wajib dibayar oleh anggota dengan besaran yang telah ditentukan secara bersama-sama. Besaran iuran wajib tersebut berbeda diantara kelompok-kelompok nelayan formal lainnya, bergantung dari kesepakatan yang dibuat oleh masing-masing anggota. Iuran yang disetorkan kepada koperasi berupa iuran wajib dan retribusi. Uang retribusi ini digunakan untuk biaya

Tabel1. Status Kelembagaan Lokal Kelompok Nelayan di Waduk Wadas Lintang, Kabupaten Wonosobo, Propinsi Jawa Tengah, Tahun 2006

Tabel 1. Local Fishers Institution Status at Wadas Lintang Reservoir, Wonosobo District, Central Java Province, 2006.

\begin{tabular}{clrrl}
\hline No & \multicolumn{1}{c}{$\begin{array}{c}\text { Desa I } \\
\text { Village }\end{array}$} & $\begin{array}{c}\text { Jumlah } \\
\text { Anggota I } \\
\text { Members }\end{array}$ & $\begin{array}{c}\text { Sifat Kelembagaan I } \\
\text { Institution Form }\end{array}$ & $\begin{array}{c}\text { Keterangan I } \\
\text { Notes }\end{array}$ \\
\hline 1 & Wadas Lintang & 59 & Formal & Koperasi/cooperation \\
2 & Sumberrejo & 20 & Formal & Koperasi/cooperation \\
3 & Sumbersari & 13 & Informal & Kelompok/group \\
4 & Kaligowong & 14 & Informal & Kelompok/group \\
5 & Plunjaran & 16 & Informal & Kelompok/group \\
6 & Elorejo & 14 & Informal & Kelompok/group \\
7 & Karanganyar & 20 & Formal & Koperasi/cooperation \\
8 & Keumejing & 25 & Formal & Koperasi/cooperation \\
\hline
\end{tabular}

Sumber: Data Primer Diolah /

Source : Primary Data Processed 
penebaran benih ikan yang dikolektifkan oleh Dinas Peternakan dan Perikanan Kabupaten Wonosobo setiap bulan sekali. Sementara uang hasil iuran wajib digunakan untuk simpan-pinjam bagi anggota dan kepentingankepentingan sosial lainnya yang terkait dengan anggota.

Selain itu, tingkat pengembalian pinjaman anggota pada kelembagan formal, baik pada kasus simpan pinjam maupun bantuan kredit dari pemerintah, sangatlah tinggi. Tingkat pengembalian ini disebabkan karena tingkat kesadaran yang tinggi dari anggota kelompok. Prioritas penerima pinjaman ditentukan dan diputuskan secara musyawarah dengan pertimbangan siapa yang lebih membutuhkan. Skema yang berjalan adalah "perguliran", yaitu pelunasan dari satu anggota akan digunakan sebagai pinjaman bagi anggota lainnya. Masingmasing anggota akan menjadi pengawas dari proses "perguliran pinjaman" tersebut. Hal lainnya berdasarkan hasil wawancara diperoleh bahwa tingkat kesadaran anggota terhadap kelestarian sumberdaya perikanan waduk juga sangat tinggi. Dalam praktek keseharian, masing-masing anggota juga berperan sebagai pengawas dari anggota lainnya dari penggunaan teknik-teknik penangkapan yang merugikan.

\section{Pilihan Strategi dan Peranan Pemerintah dalam Pengembangan Kelembagaan Lokal Nelayan Sebagai Kelembagaan Pengelolaan Waduk}

Kata kunci dari penerapan konsep comanagement adalah adanya partisipasi aktif dan representasi dari stakeholders yang terlibat, serta bersifat adaptif. Langkah awal dengan mengidentifikasi potensi-potensi sosial budaya dan kelembagaan yang ada di masing-masing lokasi. Identifikasi ini juga terkait dengan pemahaman tentang jenis-jenis stakeholders yang terlibat dalam kegiatan usaha perikanan. Tujuannya adalah untuk mendapatkan gambaran kesiapan dan pemahaman tentang pihak-pihak yang mampu menjadi inisiator, fasilitator dan akselerator dalam masyarakat.

Hasil identifikasi di atas digunakan untuk menentukan strategi yang akan digunakan oleh pemerintah dalam menguatkan dan mengembangkan kelembagaan yang ada. Berdasarkan pendekatan yang dilakukan oleh Uphoff (1986), maka strategi tersebut memiliki beberapa kondisi yang berbeda-beda. Strategi promosi diambil pada saat kondisi kelembagaan lokal yang ada belum berkembang atau tidak ada dan tidak mampu menangani permasalahan yang dihadapi dan tidak memiliki inisiatif untuk memecahkan kendala yang dihadapi. Strategi promosi ditujukan untuk re-orientasi dan penguatan kelembagaan yang sudah ada agar mampu mengatasi kendala-kendala yang ada, atau bahkan membentuk kelembagaan lokal yang sama sekali baru untuk mencapai tujuan. Strategi promosi masih melibatkan peran pemerintah yang besar dengan programprogram penyuluhan, pelatihan dan pendampingan yang sangat intensif.

Strategi fasilitasi dilakukan pada saat kelembagaan lokal sudah ada dan berkembang namun belum cukup mampu untuk mengatasi kendala-kendala yang ada, terutama terkait dengan tingkat inisiatif penyusunan program aksi yang masih rendah. Pada kondisi ini, pemerintah dapat berperan dengan memfasilitasi pendampingan dalam penyusunan rencana-rencana aksi, namun pengambilan keputusan sepenuhnya berada di pihak kelembagaan lokal.

Strategi asistensi dilakukan pada saat kondisi kelembagaan lokal yang ada telah sangat berkembang sehingga telah mampu untuk mengidentifikasi kebutuhan dan kendala yang sedang dan akan dihadapi. Berkat inisiatif dari kelembagaan lokal juga sangat tinggi terkait dengan penyusunan rencanarencana aksi pemecahan kendala yang dihadapi. Pada kondisi ini, pemerintah hanya 
berperan memonitor dan memberikan bantuan hanya pada saat diminta oleh kelembagaan lokal. Gambaran pilihan strategi pengembangan kelembagaan lokal berdasarkan pendekatan Uphoff (1986) dapat dilihat pada Gambar 2.

Sementara berdasarkan hasil identifikasi keadaan kelembagaan lokal yang ada di di perairan Waduk Wadas Lintang, maka pilihan strategi fasilitasi dapat diterapkan oleh pemerintah dalam upaya pengembangan kelembagaan kelompok nelayan di Waduk Wadas Lintang. Hal ini didasarkan atas gambaran peranan kelembagaan lokal yang ada di Waduk Wadas Lintang maka terlihat bahwa sebagian besar nelayan telah mampu mengorganisir diri dan memahami pentingnya keberadaan kelembagaan kelompok nelayan. Walaupun masih ada nelayan lainnya yang belum memiliki kesadaran akan pentingnya keberadaan kelembagaan kelompok nelayan, namun masih memiliki peluang pengembangan melalui skema penyuluhan yang terstruktur dan reguler. Hal tersebut didasarkan atas faktor penerimaan yang cukup besar dari adanya kunjungan penyuluh atau petugas pemerintah ke desa tempat mereka berada.

Dengan adanya peluang pengembangan tersebut maka sebenarnya masyarakat nelayan secara keseluruhan di Waduk Wadas Lintang dapat berpeluang dikembangkan menjadi kelembagaan pengelola waduk bersama-sama dengan pemerintah daerah setempat. Hal terpenting lainnya adalah kelembagaan penyuluhan memegang peranan yang sangat besar dari strategi pengembangan kelembagaan kelompok nelayan. Keberadaan penyuluh selama ini benar-benar dirasakan dan berperan sebagai pembina dari segala aktifitas kegiatan nelayan di Waduk Wadas Lintang. Tingkat penerimaan, dukungan dan apresiasi masyarakat nelayan juga sangat tinggi dari keberadaan penyuluh. Hal ini juga merupakan modal bagi pengembangan kelembagaan kelompok nelayan sebagai satu bagian terpenting dari strategi pengelolaan waduk secara keseluruhan.

\section{Tahapan Pengembangan Kelembagaan Kelompok Nelayan di Waduk Wadas Lintang}

Berdasarkan uraian pilihan strategi pengembangan kelembagaan lokal yaitu

Kelembagaan Lokal yang ada/ current local institution
Kuat/strong
Lemah/weak

Asal Inisiasi/inisiating source

Lokal/ local

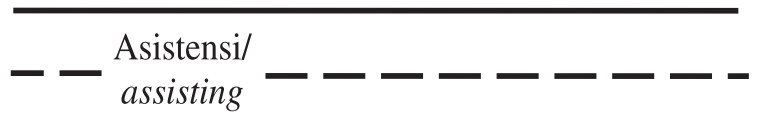

Kolaboratif/colaborative

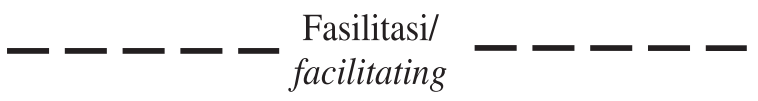

Pihak Luar/ outsides

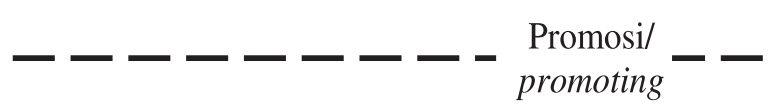

\section{Gambar 2. Pilihan Strategi Pengembangan Kelembagaan Lokal Berdasarkan Peranan Pemerintah dan Kelompok Lokal (sumber : diadaptasi dari Uphoff, 1986)}

Figure 2. Local Institutional Development Strategy Alternatives Based on Government and Local Community Roles (source : adapted from Uphoff, 1986) 
strategi fasilitasi, maka terdapat beberapa langkah-langkah yang dapat ditempuh dalam upaya pengembangan kelembagaan kelompok nelayan. Langkah-langkah tersebut dapat dibagi menjadi tahapan pembentukan dan penyusunan kelembagaan kelompok nelayan, tahapan penguatan kelembagaan kelompok nelayan dan tahapan pengembangan kelompok nelayan. Masingmasing tahapan menggunakan pendekatan partisipasi dan "learning process" dalam semua proses pengambilan keputusan.

Tahapan pembentukan dan penyusunan kelembagaan kelompok nelayan dilakukan pada lokasi-lokasi yang belum memiliki kelembagaan lokal. Pada tahapan ini, inisiasi umumnya dapat dilakukan oleh "pihak luar" yaitu melalui pemerintah, akademisi atau pun LSM. Hal-hal yang perlu diperhatikan dalam penyusunan dan pembentukan kelembagaan lokal adalah aspek representasi dan adaptif. Proses penyusunannya melibatkan secara langsung seluruh stakeholders yang ada di lokasi. Keseluruhan stakeholders tersebut diberikan kesempatan untuk menyamakan persepsi tentang pentingnya keberlangsungan usaha penangkapan ikan sekaligus sumberdayasumberdaya pendukungnya.

Upaya penyamaan persepsi ini dapat dilakukan dengan menggunakan teknik Focus Group Discussion (FGD) dalam Participatory Rural Appraisal (PRA), yaitu setiap pihak membuat assessment terhadap peluang dan kendala yang ada dalam kegiatan penangkapan ikan dengan dibimbing oleh fasilitator-fasilitator. Dengan demikian masingmasing pihak secara bersama-sama memahami kekuatan potensi dan kelemahan yang ada, sehingga secara bersama-sama dapat menyusun prioritasi aksi yang dapat dilakukan. Pada tahapan ini seluruh stakeholders juga menyusun segala perangkat aturan yang diperlukan dalam kelembagaan kelompok tersebut.
Keterwakilan setiap komponen stakeholders menjadi syarat mutlak pada setiap kelompok yang terbentuk dengan tetap mempertimbangkan kepentingan kemudahan berkoordinasi.

Tahapan penguatan kelembagaan kelompok nelayan dilakukan sebagai tahap lanjutan atau bagi lokasi yang telah memiliki kelembagaan lokal. Pada tahapan ini dilakukan dengan cara pendampingan secara langsung kepada kelompok-kelompok yang sudah ada. Pertemuan-pertemuan rutin yang juga diisi dengan berbagai jenis pelatihanpelatihan dan atau penyuluhan terkait pemahaman untuk menanamkan pentingnya keberlanjutan usaha dan lingkungan pada saat bersamaan, penggunaan teknologi ramah lingkungan, manajemen usaha, kepemimpinan dan keorganisasian.

Tahapan pengembangan kelembagaan kelompok nelayan dilakukan sebagai tahap lanjutan dengan menggunakan teknik monitoring - umpan balik. Pada tahapan ini mengikuti alur bahwa awalnya manajemen kelembagaan dilakukan secara sederhana sehingga mudah dipahami. Namun, pihak pengelola kelembagaan kelompok nelayan harus selalu terbuka menerima pendapatpendapat baru tentang pengelolaan serta mampu memodifikasi aturan-aturan berdasarkan hasil pengamatan dan pengalaman tentang kegiatan perikanan setempat atau sekitarnya. Peran kelembagaan kelompok nelayan semakin diperluas dengan peran pihak luar sebagai penyedia informasi dan pelayanan. Proses monitoring umpan balik dapat dilakukan secara bersama-sama dengan pemerintah, akademisi dan atau LSM. Proses pengembangan jejaring antara kelembagaan kelompok nelayan dengan kelembagaan kelompok lainnya difasilitasi oleh pemerintah. Hal ini mengingat kegiatan perikanan penangkapan juga sangat dipengaruhi oleh kegiatan di luar perikanan. 


\section{KESIMPULAN}

Kelembagaan yang ada di Waduk Wadas Lintang, secara umum dapat dikelompokkan menjadi dua, yaitu kelembagaan formal dan kelembagaan informal. Pengelompokkan ini didasarkan pada perbedaan status perkembangan kelompok yang telah memiliki berbadan hukum dan tidak. Perbedaan status ini memiliki pengaruh yang signifikan terhadap berjalannya kelembagaan tersebut, seperti faktor penerimaan anggota terhadap keberadaan dan fungsi kelembagaan lokal serta tingkat partisipasi anggota terhadap kegiatan kelembagaan pada kelembagaan formal secara keseluruhan lebih tinggi dibandingkan dengan kelembagaan informal. Pilihan strategi fasilitasi dapat diterapkan oleh pemerintah dalam upaya pengembangan kelembagaan kelompok nelayan di Waduk Wadas Lintang. Hal ini didasarkan atas gambaran peranan kelembagaan lokal yang ada di Waduk Wadas Lintang maka terlihat bahwa sebagian besar nelayan telah mampu mengorganisir diri dan memahami pentingnya keberadaan kelembagaan kelompok nelayan. Walaupun masih ada nelayan lainnya yang belum memiliki kesadaran akan pentingnya keberadaan kelembagaan kelompok nelayan, namun masih memiliki peluang pengembangan melalui skema penyuluhan yang terstruktur dan reguler. Hal tersebut didasarkan atas faktor penerimaan yang cukup besar dari adanya kunjungan penyuluh atau petugas pemerintah ke desa tempat mereka berada. Sementara langkah-langkah yang dapat ditempuh dalam upaya pengembangan kelembagaan kelompok nelayan terbagi menjadi tahapan pembentukan dan penyusunan kelembagaan kelompok nelayan, tahapan penguatan kelembagaan kelompok nelayan dan tahapan pengembangan kelompok nelayan. Masingmasing tahapan menggunakan pendekatan partisipasi dan "learning process" dalam semua proses pengambilan keputusan.

\section{UCAPAN TERIMAKASIH}

Penulis mengucapkan terimakasih kepada seluruh tim yang terlibat dalam penelitian : "Strategi Pengelolaan Perikanan Perairan Waduk di Pulau Jawa" yang dibiayai oleh Pusat Riset Perikanan Tangkap, BRKPDKP dan telah banyak membantu dalam pengumpulan data-data primer dan sekunder.

\section{DAFTAR PUSTAKA}

Cohen, J. M. and Peterson, S. B. 1999. Administrative Decentralization: Strategies For Developing Countries. Bloomfield, CT: Kumarian Press.

Jentoft, S., McCay, B. J and Wilson, D.C. 1998. Social Theory And Fisheries CoManagement. Marine Policy, 22(4-5), p 423-436.

Pomeroy, S. R and Berkes, F. 1997. Two To Tango: The Role Of Government In Fisheries Comanagement. Marine Policy, 21(5), p 465-480.

Rondinelli, D. 1999. What Is Decentralization? In J. Litvack and J. Seddon (Eds.), Decentralization: Briefing Notes. World Bank Institute. Washington, D.C. p. 2-5.

Satria, A and Y. Matsida. 2004. Decentralization Policy: An Opportunity for Strengthening Fisheries Management System?. Journal of Environment and Development, Vol. 13, No. 2, Sage Publications.

Stake, R. E. 1994. Case Studies in Denzin, N.K and Lincoln, Y.S [Eds]. 1994. Handbook of Qualitative Research. Sage Publications, Inc. USA. 236-247 p.

Uphoff, N. 1986. Local Institutional Development: An Analytical Sourcebook With Cases. Rural Development Committee. Cornell University. Kumarian Press.US.421 p 